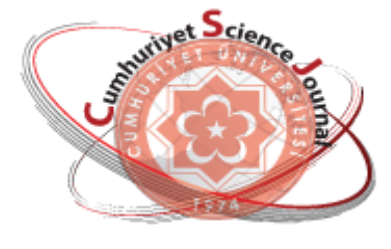

e-ISSN: $2587-246 X$

ISSN: $2587-2680$

\section{Cumburiy ot Scionee Journal esg}

Cumhuriyet Sci. J., Vol.40-4 (2019) 967-977

\title{
Investigation of Natural Mycoflora and Aflatoxin Formation in Hazelnuts and Products
}

\author{
Z. Seba KESKIN ${ }^{1}$ (D), Nevcihan GURSOY ${ }^{2}$ \\ ${ }^{I}$ Cumhuriyet University, Yildizeli Vocational School, Department of Food Technology Sivas / TURKEY \\ ${ }^{2}$ Cumhuriyet University, Faculty of Engineering, Dept. of Food Engineering, Sivas/TURKEY
}

Received: 08.11.2019; Accepted: 11.12.2019

http://dx.doi.org/10.17776/csj.644503

\begin{abstract}
In this study, natural mycoflora of 30 raw and 50 roasted hazelnut, 20 hazelnut paste and 50 inner membrane samples and their total aflatoxin contents were determined. In mycological isolations, $1.8-2.56 \%$ of Aspergillus flavus and 42.7-65.44\% of A. niger were determined in the raw hazelnut samples. A. flavus (2.2$12.2 \%$ ) and A. niger (33.3-74.5\%) were also detected in roasted hazelnut, while the percentages of these microorganisms in hazelnut paste samples were $0-13.1 \%$ and $43.5-100.0 \%$, respectively. The ratio of $A$. flavus and A. niger in inner membranes was found to be $2.6-16.2 \%$ and $44.6-89.4 \%$, respectively. Aflatoxin analysis showed that the levels of aflatoxin were $2.11-10.03 \mathrm{ppb}$ in raw hazelnut, $0.1-4.04 \mathrm{ppb}$ in roasted hazelnut, $0.2-$ $6.02 \mathrm{ppb}$ in hazelnut paste samples and 0.7-38.2 ppb in inner membrane samples. While only one of the raw hazelnut, roasted hazelnut and hazelnut paste samples had toxin above the legal limit, $100 \%$ of the inner membrane samples showed different levels of aflatoxin contamination. Since there is no limitation in the Turkish Food Codex on hazelnut inner membrane, the amount of aflatoxin, which is higher than $10 \mathrm{ppb}$ in 25 of the samples, was considered to be high contamination. Kruskal Wallis and Mann Whitney U analyses were used for statistical evaluation of the samples. There was a significant difference in aflatoxin formation and moisture content between the samples in different groups $(\mathrm{p}<0.05)$.
\end{abstract}

Keywords: Aflatoxin, hazelnut, hazelnut products, mycoflora.

\section{Fındık ve Fındık Ürünlerinde Doğal Olarak Oluşan Mikoflora İle Aflatoksin Oluşumlarinin Araştirilmasi}

Özet. Bu çalışmada, 30 çiğg, 50 kavrulmuş fındık, 20 ezme ve 50 iç zar örneğinde oluşan doğal mikoflora ve toplam aflatoksin içerikleri belirlenmiştir. Yapılan mikolojik izolasyonlarda çiğ findıkta \% 1,8-2,56 Aspergillus flavus, \%42,7-65,44 A. niger; kavrulmuş findıkta \%2,2-12,2 A. flavus, \%33,3-74,5 A. niger; ezme örneklerinde \%0-13,1 A. flavus, \%43,5-100 A. niger; iç zarda ise \%2,6-16,2 A.flavus, \%44,6-89,4 A. niger belirlenmiştir. Aflatoksin analizlerinde çiğ findıkta 2.11-10.03 ppb, kavrulmuş findıkta 0,1-4,04 ppb, ezme örneklerinde 0,2$6,02 \mathrm{ppb}$ ve iç zar örneklerinde ise $0,7-38,2 \mathrm{ppb}$ seviyelerinde aflatoksin içerikleri saptanmıştır. Çiğ fındık, kavrulmuş findık ve ezme örneklerinin sadece 1 'inde yasal sınırın üzerinde toksin içeriği bulunurken, iç zar örneklerinin \% 100' ünde değişik seviyelerde aflatoksin bulaşıklığı bulunmuştur. Fındık iç zarı ile ilgili Türk Gıda Kodeksinde bir sınırlama olmadığ için örneklerin 25' in de 10 ppb 'den yüksek olan aflatoksin oluşumları yüksek bulaşıklık olarak değerlendirilmiştir. Çalışılan örneklerin istatistikî değerlendirmelerinde Kruskal Wallis ve Mann Whitney U analizleri kullanılmıştır. Farklı gruplardaki örnekler arasında aflatoksin oluşumu ve nem içerikleri arasındaki değişim istatistiki açıdan önemli bulunmuştur $(\mathrm{p}<0.05)$.

Anahtar Kelimeler: Aflatoksin, fındık, findık ürünleri, mikoflora.

* Corresponding author. Email address: ngursoy@cumhuriyet.edu.tr,ngursoy2@gmail.com http://dergipark.gov.tr/csj $\quad$ C2019 Faculty of Science, Sivas Cumhuriyet University 


\section{INTRODUCTION}

Hazelnut (Corylus avellana L.) forms the basis for the more important commercial cultivars and is belonging to Betulaceae family. The hazelnut (Corylus avellana L.) forms the more important commercial cultivars. C. maxima and C. colurna (Turkish hazel) are also common others. Hazelnut is grown in the Blacksea Region of Turkey, especially in Trabzon, Ordu, Giresun and Akçakoca. Although vary depending on the year, Turkey ranks the first in the world with approximately 600 thousand tonnes of hazelnut production [1].

Hazelnut is a food rich in proteins, lipids, carbohydrates, vitamins, minerals, dietary fibers, tocopherols, phytosterols and phenolic compounds $[2,3]$. Monounsaturated fatty acids (especially oleic acid) and polyunsaturated fatty acids in hazelnut have been reported to have beneficial effects on human health [3]. Hazelnut oil has been found to reduce cholesterol levels in the blood [4]. Hazelnut contains tocopherols, phytosterols, squalene and phenolic compounds that help prevent chronic diseases such as cancer and cardiovascular diseases $[5,6]$.

There are biological, chemical and microbiological factors limiting hazelnut production. The most important microbiological factors limiting hazelnut production are fungal contamination and aflatoxins, one of the metabolites produced by these fungi. Aflatoxins are secondary metabolites produced by Aspergillus species. To date, more than 20 different aflatoxins have been reported. However, $B_{1}, B_{2}, G_{1}, G_{2}$ were reported to be four naturally occurring main forms. A. flavus produces only $\mathrm{AFB}_{1}$ and $\mathrm{B}_{2}$, while $A$. parasiticus produces $\mathrm{AFB}_{1}, \mathrm{~B}_{2}, \mathrm{G}_{1}$ and $\mathrm{G}_{2}$ [7-9].

Aflatoxins produced by Aspergillus spp. in field conditions, transportation, processing and storage can be found in oilseeds such as nuts, pistachios, peanuts, almonds, sunflowers, in cereals and cereal products, pulses, spices, milk, dairy products, meat, meat products and animal products such as eggs [10-12].

Aflatoxins have been reported to have several effects on human and animal health such as mutagenic, carcinogenic, teratogenic (embryonal damage), tremorgenic (problems of tremor and reflex loss), hemoralgic (tissue and organs bleeding problems), dermatitic (skin lesions), hepatoxic (liver damage), nephrotoxic (kidney system damage), and neurotoxic (nervous system damage) [13-15]. Aflatoxins are known to be the most effective hepatocarcinogen in many animal species. In many countries, aflatoxins are included in the class 1A carcinogens by the International Organization for Cancer Research, since there is a positive correlation between consumption of aflatoxin-contaminated food and an increased risk of liver cancer [16].

The maximum limits of aflatoxins in many foodstuffs have been established and published in each country. In order to protect public health, importing countries, especially the European Union countries, aim to reduce the legal values of aflatoxins to zero in risky products. To this end, aflatoxin $\mathrm{B}_{1}$ limit in many countries has been reduced from $5 \mathrm{ppb}$ to $2 \mathrm{ppb}$ and the total aflatoxin $\left(B_{1}+B_{2}+G_{1}+G_{2}\right)$ in hazelnuts has been reduced from $10 \mathrm{ppb}$ to $4 \mathrm{ppb}$ (Commission Regulation EC No 194/97). In the Turkish Food Codex, the total aflatoxin content in hazelnut and its products is determined to be $10 \mathrm{ppb}$ and Aflatoxin $\mathrm{B}_{1}$ content is maximum $5 \mathrm{ppb}[17,18]$.

As mentioned above, although vary depending on the year, Turkey ranks first in the world with approximately 600 thousand tonnes of hazelnut production [1]. In addition, Aflatoxin contamination is one of the most important problems in hazelnut and hazelnut products. Due to the aflatoxin values in nuts exported by Turkey are sometimes above the legal limits, these products are rejected by the countries, which leads to huge economic losses. Additionally, producers and industrialists are struggling economically, Turkey's reputation in foreign trade is damaged and marketing problems arise.

After the occurrence of aflatoxin, which is a problem in food all over the world, they cannot be controlled [19-21].Therefore, the most effective method for the formation of aflatoxins produced by fungi is to harvest, dry, store and process food under conditions that reduce the risk of contamination and limit the development of fungi. These conditions can only be achieved by determining the natural mycoflora that is formed in the product and can cause toxin formation.

In this study, it was aimed to determine the naturally occurring mycoflora in raw hazelnut, 
roasted hazelnut, hazelnut paste and hazelnut inner membrane and to investigate the total aflatoxin formation in these products.

\section{MATERIALS AND METHODS}

\subsection{Supply of Hazelnut Samples}

The samples used in the study were obtained from various factories and retail stores in Trabzon, Ordu, Giresun and Akçakoca regions where hazelnut production is intense in the Blacksearegion. In the sampling, raw hazelnut $(\mathrm{n}=30)$, roasted hazelnut $(\mathrm{n}=50)$, hazelnut paste $(\mathrm{n}=20)$, and inner membrane $(n=50)$ samples were used. The hazelnut samples were provided immediately after harvest, the inner membrane samples were obtained during the drying period and the hazelnut paste samples were provided during the processing stages of the product. Samples were brought to the laboratory under appropriate conditions and kept in labelled cloth bags and refrigerated at $4{ }^{\circ} \mathrm{C}$ until tested.

\subsection{Determination of Moisture Content of Samples}

The moisture content of the hazelnut, hazelnut paste and membrane samples used in the study was determined by a precision balance and halogen lamp moisture analyzer according to the method reported by Bakker [22]. $5.0 \pm 0.1 \mathrm{~g}$ of raw and roasted hazelnut samples were taken and shredded in hand blender and moisture contents were determined at $140{ }^{\circ} \mathrm{C}$. In order to determine the moisture content of hazelnut membrane and hazelnut paste samples, $1 \mathrm{~g}$ of each sample was weighed directly without any process and evaluated according Özkaya [23] equation (1).

$$
\% \text { Moisture content: } \frac{M_{1}-M}{M_{1}-M_{0}}
$$

$M_{0:}$ Weight of continer (Tare) $(\mathrm{g})$

$M$ : Weight of the container and sample after drying $M_{1}$ : Weight of sample with container

\subsection{Mycological Isolations}

Raw hazelnut, roasted hazelnut and inner membrane samples were sterilized with $2.0 \%(\mathrm{v} / \mathrm{v})$ $\mathrm{NaOCl}$ solution and washed with distilled water. After surface sterilization, of dried hazelnut, roasted hazelnut and inner membrane samples, hazelnut paste samples were added directly to Potato Dextrose Agar (PDA). After surface sterilization was performed, raw hazelnut, roasted hazelnut and inner membrane samples were dried and then planted in PDA while surface sterilization process was not applied for the cultivation of hazelnut paste samples. A total of 100 plantings were made for each sample using 10 petri dishes. Cultivated petri dishes were incubated at $24{ }^{\circ} \mathrm{C}$ for 4-5 days and thus colony development was ensured. At the end of incubation, the fungal colonies were differentiated based on macroscopic criteria such as size, colour, surface or overhead development, and colonies showing different growth were purified by classifying as Fusarium (F1, F2,..), Aspergillus (A1, A2, ...) and Penicillium (P1, P2,...).

After purification, single spore isolation was made on water and Czapek Dox Agar. Single spore isolates were incubated at $25{ }^{\circ} \mathrm{C}$ for 7 days by transferring them to a suitable growth medium. Cultures were examined under microscope during the incubation and general morphological definitions were made, colony number and characteristics were recorded.

Specific diagnostic keys have been used for the fungi species identified intensively as a result of mycological isolations. While the diagnostic keys developed by Raper and Fennel [24] and Samson and Pitt [25] is used for the identification of Aspergillus species, Penicillum species were identified according to the diagnostic keys of Samson et al. [26] and Pitt [27]. In identifying Fusarium and other species, diagnostic key developed by Barnett and Hunter [28] was used.

In species identification of fungi; growth rates at certain temperatures (colony diameter and properties), overhead mycelium formation (colour and structure), the presence or absence of chlamidospores, sporodosium development, fialitic properties, conidial cap (color and shape), conidial sequencing, colony colours, presence or absence of sclerotes, and presence of macro and micro conidia were evaluated.

\subsection{Aflatoxin Analysis}

CD-ELISA (Competitive Direct Enzyme-Linked Immuno Sorbent Assay) method was used to investigate the total amount of aflatoxin in raw hazelnut, roasted hazelnut, inner membrane and hazelnut paste samples. 5 different aflatoxin standards were used in CD-ELISA at 0, 1, 2, 4 and 8 ppb levels. Samples were prepared and extracted according to the procedure of Neogen Veratox ${ }^{\circledR}$. CD-ELISA results were obtained by reading at 650 $\mathrm{nm}$ in a microwell reader. Veratox Software for Windows, Log/Logit and Single Test Format v3.02 software were used to calculate the toxin values in ppb. 


\section{RESULTS AND DISCUSSION}

Moisture measurement analyzes were carried out to determine how moisture content of raw hazelnut, roasted hazelnut, inner membrane and hazelnut paste affect natural mycoflora and aflatoxin formation in these samples.

The moisture content of samples obtained from Trabzon, Ordu, Giresun and Akçakoca regions are given in Figure 1.

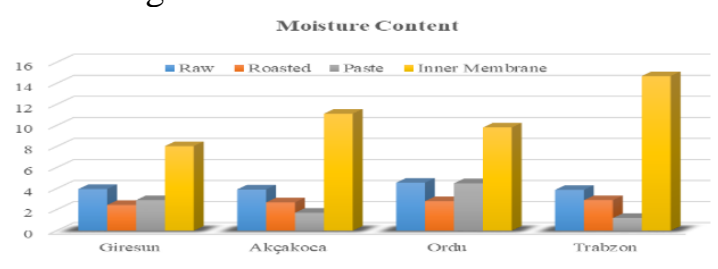

Figure 1. Moisture content of samples obtained from different regions

As can be seen from Figure 1, the moisture values of the raw hazelnuts were determined as 3.88$4.56 \%$. It is recommended that the maximum moisture content in raw hazelnuts should be max. $4.5 \%$ [29]. It was observed that the moisture values of our samples were close to or higher than the recommended maximum value. Aluç and Aluç [30] found the moisture values of 186 Akcakoca, 177 Ordu and 160 Giresun raw hazelnut samples to be 4.2-6.8\%. According to meteorological data, the rainfall of the 4 regions is approximately 61.6-75.9 $\mathrm{mm}$ per year. Samples of raw nuts with the highest moisture content were obtained from Ordu region. This is due to the fact that the average annual rainfall in the Ordu region is generally higher than the other three regions.

As a result of mycological isolation of raw hazelnut, roasted hazelnut, hazelnut paste and inner membrane samples, Aspergillus species were observed as the most dominant fungal ones. Natural mycoflora determined as a result of mycological isolations in samples obtained from different regions is presented in Table 1 and Figure 2. Aspergillus and Penicillium species are predominant in the studies conducted on the determination of raw and roasted hazelnut mycoflora, however, Rhizopus, Fusarium, Cladosporium, Trichothecium, Mucor, Alternaria and Trichoderma species have also been reported to be isolated [31, 32]. No studies have been found in the literature on the determination of mycoflora in hazelnut paste and inner membrane samples.

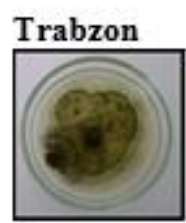

a

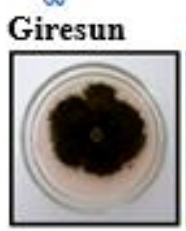

1

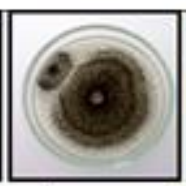

b

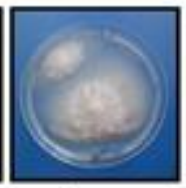

j

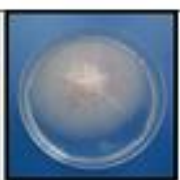

c

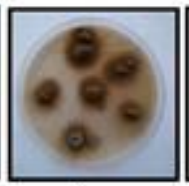

$\mathbf{k}$

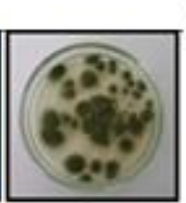

d

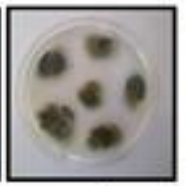

1

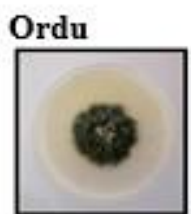

e

Akçakoca

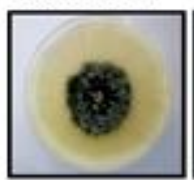

$\mathbf{m}$

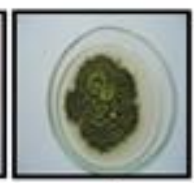

f

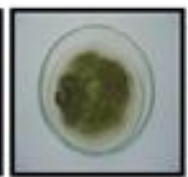

n

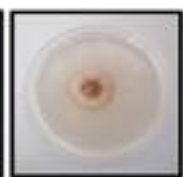

g

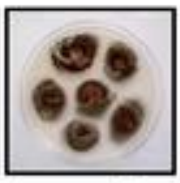

h

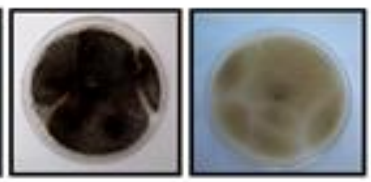

o

p

a. A. flavus from raw nuts; b. A. niger from roasted nuts; c. Fusarium spp. from hazelnut butter; d. Penicillium spp. from the inner membrane; e. Trichoderma spp. from raw nuts; f. A. flavus from roasted hazelnuts; g. Fusarium spp. from hazelneut butter; h. A. niger isolated from the inner membrane $\mathbf{1}$. A. flavus from raw nuts; j. Fusarium spp. from roasted hazelnuts; $\boldsymbol{k}$.Trichoderma spp. isolated hazelnut butter; l. Penicillium spp. isolated from inner membrane; m. Tricoderma spp. from raw nuts; $\quad$ n. A. flavus from roasted hazelnuts; $\boldsymbol{o}$. A. niger from hazelneut butter; p. Tricoderma spp. from the inner membrane.

Figure 2. Isolated fungal species from sample groups. 


\begin{tabular}{|c|c|c|c|c|c|c|c|}
\hline Regions & $\begin{array}{l}\text { Sample } \\
\text { Type }\end{array}$ & Fungus Species & \% Isolation & Regions & $\begin{array}{l}\text { Sample } \\
\text { Type }\end{array}$ & Fungus Species & $\%$ Isolation \\
\hline \multirow{15}{*}{ 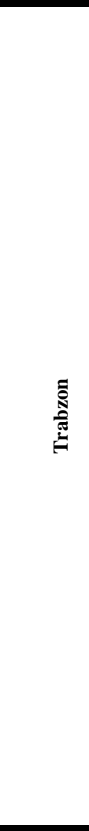 } & \multirow{3}{*}{ 婄 } & Aspergillus & 68.0 & \multirow{16}{*}{ 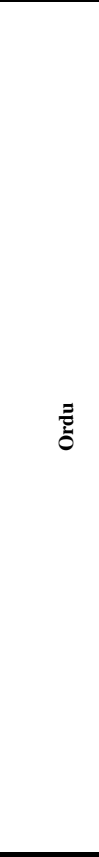 } & \multirow{5}{*}{$\stackrel{\text { E }}{\dddot{E}}$} & Aspergillus & 63.0 \\
\hline & & Penicillium & 19.2 & & & Penicillium & 23.3 \\
\hline & & Rhizopus & 12.8 & & & Rhizopus & 9.4 \\
\hline & \multirow{5}{*}{ 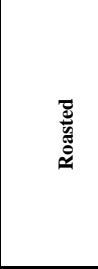 } & Aspergillus & 57.8 & & & Fusarium & 2.6 \\
\hline & & Penicillium & 26.6 & & & Trichoderma & 1.7 \\
\hline & & Fusarium & 8.4 & & \multirow{4}{*}{ 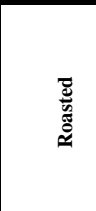 } & Aspergillus & 44.5 \\
\hline & & Alternaria & 4.6 & & & Penicillium & 33.5 \\
\hline & & Rhizopus & 2.6 & & & Fusarium & 16.5 \\
\hline & \multirow{3}{*}{$\stackrel{\bar{\Xi}}{\bar{\Xi}}$} & Aspergillus & 50.3 & & & Rhizopus & 5.5 \\
\hline & & Penicillium & 43.5 & & \multirow{4}{*}{ 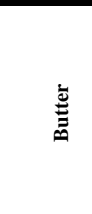 } & Aspergillus & 51.0 \\
\hline & & Fusarium & 6.2 & & & Penicillium & 20.6 \\
\hline & \multirow{4}{*}{ 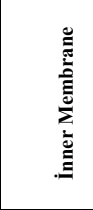 } & Aspergillus & 60.6 & & & Rhizopus & 18.0 \\
\hline & & Penicillium & 33.0 & & & Fusarium & 10.4 \\
\hline & & Rhizopus & 4.0 & & \multirow{3}{*}{ 产 } & Aspergillus & 95.0 \\
\hline & & Trichoderma & 1.4 & & & Penicillium & 4.4 \\
\hline \multirow{16}{*}{ 志 } & \multirow{4}{*}{ 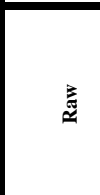 } & Aspergillus & 45.0 & & & Rhizopus & 0.6 \\
\hline & & Penicillium & 21.0 & \multirow{15}{*}{ 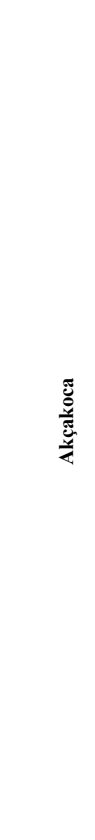 } & \multirow{5}{*}{$\stackrel{\text { E }}{\underline{E}}$} & Aspergillus & 54.2 \\
\hline & & Rhizopus & 21.0 & & & Penicillium & 14.6 \\
\hline & & Fusarium & 13.0 & & & Rhizopus & 14.6 \\
\hline & \multirow{3}{*}{ 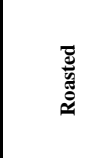 } & Aspergillus & 78.5 & & & Fusarium & 8.3 \\
\hline & & Penicillium & 17.5 & & & Trichoderma & 8.3 \\
\hline & & Fusarium & 4.0 & & \multirow{4}{*}{ 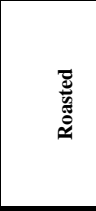 } & Aspergillus & 45.2 \\
\hline & \multirow{5}{*}{$\stackrel{\bar{\Xi}}{\bar{\Xi}}$} & Aspergillus & 63.7 & & & Rhizopus & 27.0 \\
\hline & & Penicillium & 23.7 & & & Penicillium & 18.3 \\
\hline & & Trichoderma & 10,0 & & & Fusarium & 9.5 \\
\hline & & Rhizopus & 2,0 & & \multirow{2}{*}{ 总 } & Aspergillus & 81.3 \\
\hline & & Fusarium & 0,6 & & & Penicillium & 18.7 \\
\hline & \multirow{4}{*}{ 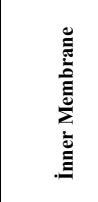 } & Aspergillus & 4.8 & & \multirow{4}{*}{ 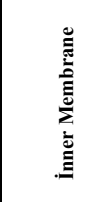 } & Aspergillus & 85.1 \\
\hline & & Penicillium & 34.4 & & & Penicillium & 9.3 \\
\hline & & Trichoderma & 12.2 & & & Trichoderma & 4.7 \\
\hline & & Rhizopus & 5.6 & & & Rhizopus & 0.9 \\
\hline
\end{tabular}




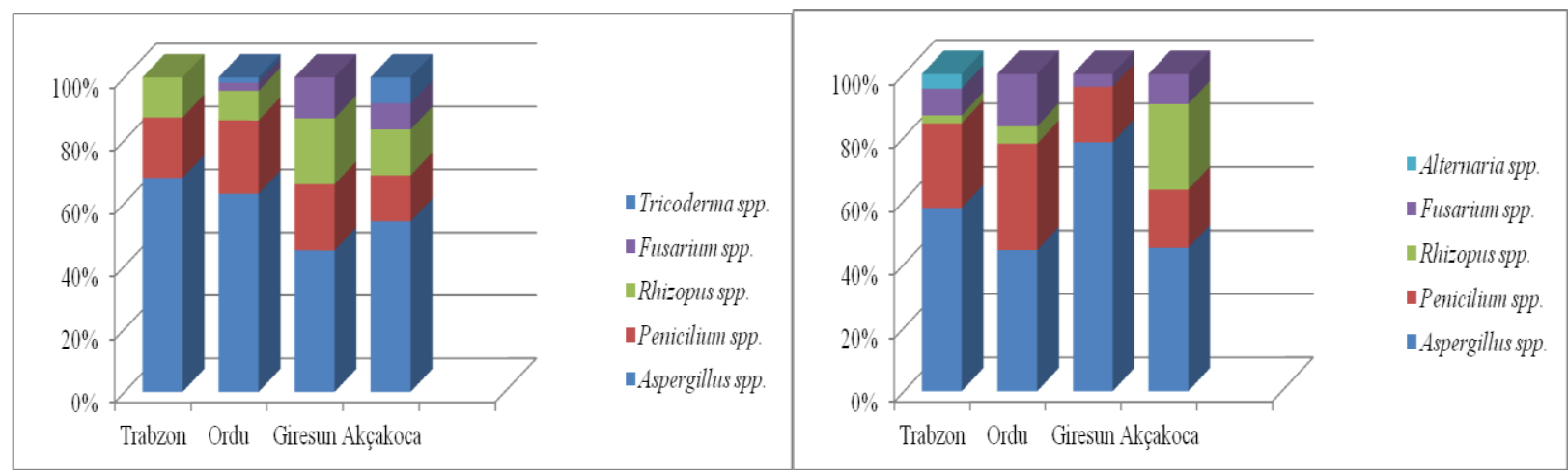

Figure 3. Fungus genus isolated from raw and roasted hazelnut samples.

Mycoflora in raw hazelnut was determined to be 45-68\% of Aspergillus spp., 14.6-23.3\% of Penicillium spp., 9.4-21\% of Rhizopus spp., 2.6$13.0 \%$ of Fusarium spp., and $1.7-8.3 \%$ of Trichoderma spp. These ratios were found to be as follows in the mycoflora of roasted hazelnuts: 44.5 78.5\% Aspergillus spp., 17.5-33.5\% Penicillium spp., 2.6-27.0\% Rhizopus spp., 4.0-16.5\% Fusarium spp., 0.0-4.0\% Alternaria spp. (Figure $3)$.

Various studies on the determination of natural microflora in raw and roasted hazelnuts yield similar results to the present study. In these studies, although Aspergillus and Penicillium species were dominant, Rhizopus, Fusarium, Cladosporium, Trichothecium, Mucor, Alternaria and Trichoderma species were also isolated [31-34]. Aspergillus spp. was found to be high in natural mycoflora of raw and roasted hazelnuts in many studies [35-37].Other fungi genus and their proportions isolated from raw nuts are as follows: 12.8-23.3\% Rhizopus spp., 9.4-19.2\% Penicillium spp., 2.6-13\% Fusarium spp. and 1.7-8.3\% Trichoderma spp. According to a study carried out by Demir et al. [38] on 30 raw hazelnut samples, the most commonly isolated fungi genus have been reported as follows: 2.2- 100.0\% Aspergillus spp., 4.0-67.4\% Penicillium, 2.0-62.0\% Rhizopus, 2.0$82.0 \%$ Mucor and 2.0-56.0\% other fungus genera. Simsek et al. [39], identified $96.6 \%$ Aspergillus spp., 93.3\% Penicillium, 96.6\% Rhizopus and 83.3\% Mucor in 30 hazelnut samples obtained from Giresun. It is thought that the reason of high observation of the Aspergillus spp. in many of our samples is that the hazelnut was exposed to fungal contamination in the tree and during harvest. Furthermore, this indicates that although the product is harvested early and the shell forms a protective layer, there is a risk of contamination from cracks that may occur during harvest. In addition, high moisture content of hazelnut growing areas is one of the important factors that promote the development of Aspergillus spp.

According to our literature search could ascertain, no study is available on natural mycoflora formed in hazelnut inner membrane and hazelnut paste. However, it is thought that the data obtained from this study will serve as an example for other scientific studies in the future. As can be seen from Figure 4, 47.8-95.0\% Aspergillus spp., 4.4-34.4\% Penicillium spp., 1.4- 12.2\% Trichoderma spp., and 0.6-4.0\% Rhizopus spp. was determined in the inner membranes of hazelnuts samples collected from 4 regions. Unidentified fungi species were ignored. From hazelnut paste samples, 50.3-81.3\% Aspergillus spp., 18.7-43.5\% Penicillium spp., 2.018.0\% Rhizopus spp., 0.0-10.0\% Trichoderma spp. and 0.6-10.4\% Fusarium spp. were isolated.

Although Aspergillus spp. species that can synthesize aflatoxin in hazelnut paste samples are different according to regions, they have been isolated and identified as the most dominant species in the present study by $50.3-81.3 \%$. Penicillium, Rhizopus, Fusarium and Trichoderma strains were isolated in $18.7-43.5 \%, 2.0-18.0 \%$, $0.6-10.4 \%$ and $0.0-10.0 \%$, respectively in mycoflora of hazelnut paste samples. 


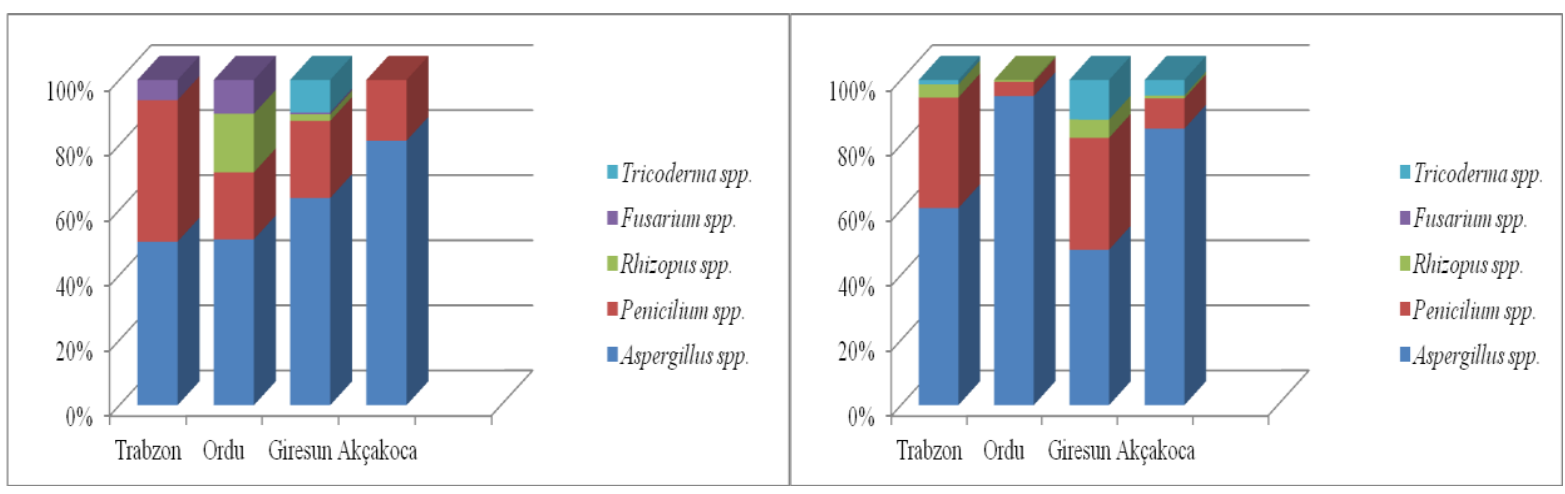

Figure 4. Fungus genus isolated from hazelnut paste and inner membrane samples. outer shells [31]. This is because the hard shell of

The high rate of Aspergillus spp. species in most of our samples suggests that hazelnut is exposed to fungal contamination in the tree and during harvest.

This is because the development of Aspergillus spp. species in shelled hazelnuts starts on the surface of the shell when it is still in the tree, and it can increase during the contact of the product with the soil and harvesting. Aspergillus spp. are not seen in shelled hazelnuts that come into contact with the ground, while A. flavus-parasiticus develops in the hazelnut which is damaged in the hazelnut is a good protector against fungal contamination and bacteria.

$50 \%$ of the total 150 raw hazelnuts, roasted hazelnuts, hazelnut paste and inner membranes, aflatoxin contamination was found to be at levels of 0.1-38.2 ppb. Aflatoxin levels of 2.11-10.03 ppb were determined in 9 of 30 raw hazelnut samples and only one sample had aflatoxin content above the legal limit. Aflatoxin contamination (14.0\%) and aflatoxin levels (0.1-4.04 ppb) were below the legal limit in roasted hazelnut samples (Table 2).

\begin{tabular}{|l|c|c|c|c|c|}
\hline \multicolumn{6}{|c|}{ Table 2. Toxin contents and contamination rates determined in the samples } \\
\hline Sample & $\begin{array}{c}\text { Number } \\
\text { of } \\
\text { Samples }\end{array}$ & $\begin{array}{c}\text { Aflatoxin } \\
(\mathbf{p p b})\end{array}$ & $\begin{array}{c}\text { Contaminated } \\
\text { Samples }\end{array}$ & $\begin{array}{c}\text { Exceeding } \\
\text { Legal Limit }\end{array}$ & $\begin{array}{c}\text { \% } \\
\text { Contamination }\end{array}$ \\
\hline Raw & 30 & $2,11-10,03$ & 9 & 1 & 30 \\
\hline Roasted & 50 & $0,1-4,04$ & 7 & - & 14 \\
\hline $\begin{array}{l}\text { Hazelnut } \\
\text { Butter }\end{array}$ & 20 & $0,2-6,02$ & 9 & - & 45 \\
\hline $\begin{array}{l}\text { Inner } \\
\text { Membran }\end{array}$ & 50 & $0,7-38,2$ & 50 & 25 & 100 \\
\hline
\end{tabular}

As a result of statistical evaluations between the moisture contents and aflatoxin formation of 4 different hazelnut samples obtained from different regions, the relationship between moisture content and aflatoxin formation was found to be significant $(p<0.05)$ (Figure 5). 


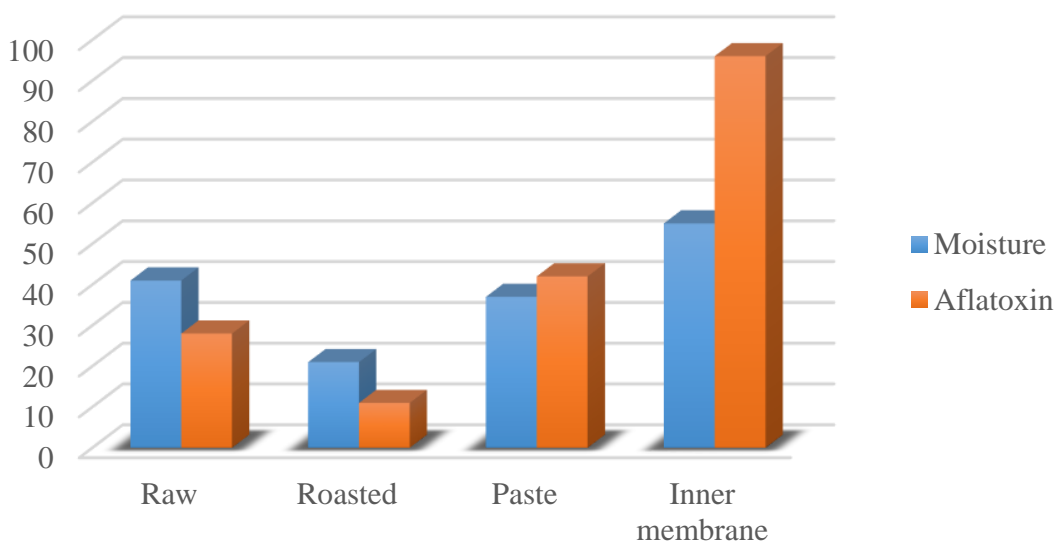

Figure 5. The relationship between moisture content and aflatoxin formation. examined and aflatoxin was determined in 5 of 25

While the amount of aflatoxin was found to be $30 \%$ in the studied hazelnut samples, in only one of the samples obtained from 4 regions, total aflatoxin levels exceeded $10 \mathrm{ppb}$, which is the legal limit of aflatoxin determined by the Turkish Food Codex. Aycicek et al. [40] have studied the total aflatoxin levels in raw hazelnuts. According to this study, only one of 51 raw hazelnut samples has been reported to exceed this legal limit. Especially in raw hazelnut samples, high moisture content and therefore aflatoxin content were detected in high rainfall areas, indicating that climatic data play an important role. Aluç and Aluç [30] determined the

levels of aflatoxins in raw nuts obtained from Akçakoca, Ordu and Giresun. In 10 of 186 lots raw nuts from Akcakoca region $B_{1}=2.66-75.08 \mathrm{ppb}$, total $=4.77-78.93 \mathrm{ppb}, 20$ of 160 lots raw nuts from Giresun region $\mathrm{B}_{1}=2.17-75.68 \mathrm{ppb}$, total $=4.34$ $150,08 \mathrm{ppb}$, and 16 of 177 lots raw nuts from Ordu region $\mathrm{B}_{1}=2.1-29.44 \mathrm{ppb}$, total $=3.61-135.51 \mathrm{ppb}$ aflatoxin contamination. Due to the high rainfall in the regions where raw hazelnuts are grown, factors such as high moisture values and the fact that hazelnuts are not fully developed while in the tree cause aflatoxin formation. In addition, mistakes made during the production, processing and storage stages lead to an increase in the amount of aflatoxin.

Aflatoxin was determined in 7 of the 50 roasted hazelnut samples and total amount of aflatoxin was between 0.1-4.04 ppb. The amount of aflatoxin found in the samples was found to be below the legal limit specified in the Turkish Food Codex. Heperkan [31] has investigated the mycotoxins in foods and their importance in terms of our country. In this study, 140 samples obtained from Ordu, Giresun and Tirebolu in Blacksearegion were hazelnut samples. Deabes and Al-Habib [34] reported that Aspergillus species, which are capable of producing aflatoxin, were predominant in mycoflora of hazelnut samples and aflatoxin levels were found to be between 41-55 ppb.

Aflatoxin content was found to be $14.0 \%$ in roasted hazelnut samples. This value was found to be lower than in raw hazelnut. Raw nuts are more risky in terms of aflatoxin, while roasted nuts are more stable [41]. The reason for this is that some fungi in the mycoflora become ineffective and the moisture content decreases as a result of heat treatments applied to roasted hazelnuts. Because fungal contamination is more common due to the high rate of free water required for the development of fungi. In addition, as the fat content of the products increases, the rate of mold and aflatoxin increase [42].

In a study, aflatoxin levels were investigated in hazelnuts. Aspergillus species capable of producing aflatoxin in the mycoflora of hazelnut samples analyzed have been reported to be predominant and aflatoxin levels vary between 41$55 \mathrm{ppb}$ [34].

In a study investigating natural mycoflora and aflatoxin contamination in 25 raw and 25 roasted hazelnut samples, aflatoxin contamination was reported in $33(66 \%)$ of 50 hazelnut samples at $0.1-$ $155 \mathrm{ppb}$ levels. In this study, aflatoxin formation above the legal limit was determined at 14.2-155 ppb levels in 2 raw and 6 roasted hazelnut samples [32].

Baltac1 et al. [43], have collected samples during 3 years from companies exporting raw and roasted hazelnuts. According to the results of this study, 
aflatoxin levels were found to be between 0.02$78.98 \mathrm{ppb}$ in 3188 samples. It was determined that 3147 of these samples had aflatoxin below the legal limits and 41 of them were well above the legal limits.

The amount of aflatoxin was found to be $100 \%$ in hazelnut inner membrane. It is noteworthy that aflatoxin levels reach a high rate of 0.7-38.2 ppb. However, since there is no limitation of aflatoxin in the inner membrane in Turkish Food Codex, our samples could not be evaluated in this respect. Hazelnut membrane is a thin and brown perisperm layer that completely encapsulates the hazelnut grain and is released as a by-product during roasting process. The antioxidant capacity of hazelnut membrane is high and it is also considered as dietary fiber $[44,45]$. In the Blacksearegion, hazelnut inner membrane is used for different purposes such as animal feed and soil fertilizer. The absence of a legal limitation for aflatoxin contamination in the hazelnut membrane is highly risky for the health. Therefore, it is thought that it should be controlled with legal restrictions. While studies have been conducted to determine whether the hard shell protects the hazelnut against fungal contamination and thus aflatoxin formation, there is not enough work on the inner membrane. However, in a study by Özer [46] the aflatoxin content of the membrane was examined after roasting and peeling of the hazelnuts. In addition to natural contaminated hazelnuts, hazelnuts were artificially contaminated with Aspergillus flavus to contain aflatoxin at levels 10 and $20 \mathrm{ppb}$. According to the data obtained from the study, roasting, manual separating, mechanical separating and membrane peeling were found to reduce aflatoxin contamination and Aflatoxin $\mathrm{B}_{1}$ content in hazelnuts. Aflatoxin $B_{1}$ level before the first roasting process was $11.28 \mathrm{ppb}$. this value was found to be $11.11 \mathrm{ppb}$ after roasting. This value decreased to $0.23 \mathrm{ppb}$ after peeling of the membrane. In the membrane, Aflatoxin $\mathrm{B}_{1}$ (12.71 $\mathrm{ppb}$ ) was reported to be higher than hazelnut. It has been reported that aflatoxin is concentrated in the membrane and damaged hazelnuts and the average reduction in aflatoxin contamination after operations is reported to be $98 \%$.

Aflatoxin levels of 0.2-6.02 ppb were determined in 9 of 20 hazelnut paste samples used in the study. Although the rate of aflatoxin contamination in the samples was $45 \%$, none of them exceeded the legal limit specified in the Turkish Food Codex (max.5 ppb for aflatoxin B1, max. $10 \mathrm{ppb}$ for total aflatoxin). Vural et al. [47] examined 180 hazelnut paste samples consumed in Istanbul in terms of aflatoxin $B_{1}$ and total aflatoxin and found that $6.59 \%$ of the samples exceeded the legally acceptable maximum level. Günşen and Büyükyörük [48] reported that there were an average of $1076.5 \pm 194.4 \mathrm{ppb}$ aflatoxin $\mathrm{B}_{1}$ in 25 cocoa hazelnut paste obtained from various markets in Bursa. Yu et al., [49] reported that the majority of aflatoxins are better produced by fungi in glucose, fructose-containing media. It is thought that hazelnut, which is a good substrate for Aspergillus species and sugar added as an additive in hazelnut paste may have increased aflatoxin production in hazelnut paste. The rate of contamination in the hazelnut paste analysed cannot be ignored. This situation makes us think that businesses producing hazelnut paste, which is a food consumed especially by young people and children, should be more careful in hazelnut intake, operational hygiene and storage.

\section{CONCLUSION}

The weather in the Black Sea region is rainy and continuously the harvesting season is very humid, increasing the risk of Aflatoxins contamination. Fungal contamination and consequently aflatoxins formation can occur in hazelnuts, at pre-harvest, harvest, during post-harvest applications and also in storage. According to this study results indicate that, although the risk of aflatoxin formation is present in hazelnuts and products, the most important stages to prevent aflatoxin occurrence are harvesting and drying methods including storage.

\section{ACKNOWLEDGMENTS}

This study was accepted by the Institute of Science and Technology of Sivas Cumhuriyet University and supported financially by the Scientific Research Council of Sivas Cumhuriyet University (CUBAP M-434).

\section{REFERENCES}

[1] TUIK., Agricultural production values. www.tuik.gov.tr (2016). (Access date: 09/09/2018).

[2] Alasavar C., Shahidi F., Liyanapathirana C.M., Oshima T., Turkish Tombul Hazelnut (Corylus Avellena L.) 1. Compositional Characteristics, Journal of Agricultural and Food Chemistry, 51(2003) 3790-3796. 
[3] Alasalvar C, Amaral JS, Shahidi F.. Functional lipid characteristics of Turkish Tombul hazelnut (Corylus avellana L.). J Agric Food Chem. 54 (2006) 10117-10183.

[4] Durak I., Köksal I., Kacmaz M., Büyükkocak S., Cimen B.M.Y., Ozturk H.S., Hazelnut supplementation enhances plasma antioxidant potential and lowers plasma cholesterol levels. Clinica Chimica Acta. 284 (1999) 113-115.

[5] Maguire L.S., O'Sullvian S.M., Galvin K., O'Connor T.P., Brien N.M., Fatty acid profile, tocopherol, squalene, and phytosterol content of walnut, almonds, peanuts, hazelnuts, and macadamia nut. Int $\mathbf{J}$ Food Sci. 3 (2004) 171-178.

[6] Shahidi F., Alasalvar C., Liyana-Patharina C.M., Antioxidant and phytochemicals in hazelnut kernel (Corylus avellana L.) and hazelnut by-products. J Agric Food Chem. 55 (2007) 1212-1220.

[7] Quillien J.F., Mycotoxins. (2002) http://www.fevia.be/pdf/20pagers/synth/my cotoxins.pdf.

[8] Hussain I., and Anwar J., A study on contamination of aflatoxin $\mathrm{M} 1$ in raw milk in the Punjab province of Pakistan. Food Control 19 (2008) 393-395.

[9] Samuel M.S., Sivaramakrishna A., Mehta, A., Degradation and detoxification of aflatoxin B1 by Pseudomonas putida. Int. Biodeterioration and Biodegradation, 86 (2014) 202-209.

[10] Bullerman L.B., Schroeder L. L., Park K.Y., Formation and Control of Mycotoxins in Food, Journal of Food Protection, 47 (1984) 637-646.

[11] Severns D. E., Clements M. J., Lambert R. J., and White D. G., Comparison of Aspergillus ear rot and aflatoxin contamination in grain of high oil and normal oil corn hybrids. J. Food Prot. 66 (2003) 637-643.

[12] Alsuhaibani, A.M.A., Effects of Storage Periods and Temperature on Mold Prevalence and Aflatoxin Contamination in Nuts. Pak. J. Nutr., 17 (2018) 219-227.

[13] Amaike S.A., and Keller N.P., Aspergillus flavus. Annu.Rev.Phytopath. 49 (2011)107133.

[14] Kensler T.W., Roebuck B.D., Wogan G.N., and Groopman J.D., Aflatoxin: a 50-year odyssey of mechanistic and translational toxicology. Toxicol.Sci.120 (2011) 28-48.
[15] Roze L.V., Hong S.Y., and Linz J.E., Aflatoxin biosynthesis: current frontiers. Annu. Rev. Food Sci.Technol.4 (2013) 293 311.

[16] IARC., Some Naturally Occurring Substances: Food Items and Constituents, Heterocyclic Aromatic Amines and Mycotoxins, in IARC Monographs on The Evaluation of Carcinogenic Risks to Humans, 56 (1993) 489-521.

[17] Afsah-Hejri L., Jinap S., Arzandeh S., Mirhosseini H., Optimization of HPLC conditions for quantitative analysis of aflatoxins in contaminated peanut. Food Control, 22 (2011) 381-388.

[18] Ding X., Peiwu L., Bai Y., Zhou H., Aflatoxin B1 in post-harvest peanuts and dietary risk in China. Food Control, 23 (2012) 143-148.

[19] Chen Y.C., Liao C.D., Lin H.Y., Chiueh L.C., Survey of aflatoxin contamination in peanut products in Taiwan from 1997 to 2011. Journal of Food and Drug Analysis, 21 (2013) 247-252.

[20] Torres A.M., Barros G.G.. Palacios S.A. Chulze S.N., Battilani P., Review on preand post-harvest management of peanuts to minimize aflatoxin contamination. Food Research International, 62 (2014) 11-19.

[21] Kumar P., Dipendra K.M., Madhu K., Tapan K.M., and Sang G.K., Aflatoxins: A Global Concern for Food Safety, Human Health and Their Management. Frontiers in Microbiology, 2 (7) (2017) 2170.

[22] Bakker F.W., Grains and Grain Quality. CIGR Handbook of Agricultural Engineering, Volume IV Agro-Processing Engineering. The American Society of Agricult. Eng. (1999) 1-3.

[23] Özkaya H., Analitik Gıda Kalite Kontrolü, Ankara Üniv. Ziraat Fak. Yay. 108 s., Ankara.

[24] Raper K.B. and Fennell, D.I., The Genus Aspergillus. Robert E. Krieger Publishing Company Huntington, New York, (1977) 686.

[25] Samson R.A. and Pitt I.J., Modern Concepts in Penicillium and Aspergillus Classification, NATO ASI Series, Plenum Press, New York and London, 185 (1990) 478.

[26] Samson R.A, Stolk A.C., Hadlock R., Revision of The Subsection Fasciculata of Penicillium and Some Allied Species, Stud. Mycol. Baarn, 11 (1976) 1-47. 
[27] Pitt J.I. A Laboratory Guide to Common Penicillium Species, Food Science, Australia, Mycologia, 93 (2000) 689-703.

[28] Barnet H.L. and Hunter B.B., Illustrated Genera of Imperfect Fungi, Third Edition, Burgess Publishing Company (1997).

[29] Çetin Ö., Nazlı B., Bostan K., Alperden İ., Depolamanın Çiğ İç Fındığın Kalitesi Üzerine Etkileri, İst. Vet. Fak. Der., 26 (2000) 413-419.

[30] Aluç M., Aluç S., Akçakoca, Ordu ve Giresun Yörelerinde Yetiștirilen Fındıklarda Aflatoksin Düzeyinin Belirlenmesi Üzerine Bir Çalışma, Ulusal Mikotoksin Sempozyumu. İstanbul (2003) 60-67.

[31] Heperkan D., The Importance of Mycotoxins and a Brief History of Mycotoxin Studies in Turkey, The Bulletin İstanbul Tech. Uni.,54 (2003) 18-27.

[32] Gürsoy, N., Çiğ ve Kavrulmuş Fındıklardaki Mikoflora ve Aflatoksin Bulaşıklıklarının Değerlendirilmesi, Türkiye 10. Gida Kongresi (2008) Erzurum.

[33] Jimenez M., Mateo R., Quero, A., Huerta T., Hernandez E., Mycotoxins and Mycotoxigenic Moulds in Nuts and Sunflower Seeds for Human Consumption, Mycopathologia,115 (1991) 121-7.

[34] Deabes M,. and Al- Habib R., Toxigenic Fungi and Aflatoxin Associated to Nuts in Saudi Arabia, Journal of American Science, 7 (2011) 658-665.

[35] Gürses M., Mycoflora and Aflatoxin Content of Hazelnuts, Walnuts, Peanuts, Almonds and Roasted Chickpeas (Leblebi) Sold in Turkey, J. of Food Properties, 9 (2006) 39-399.

[36] Ostadrahimi A., Ashrafnejad F., Kazemi A., Sargheini N., Mahdavi R., Farshchian M., Aflatoxin in raw and salt-roasted nuts (pistachios, peanuts and walnuts) sold in markets of Tabriz, İran. Jundishapur. J Microbiol. 7 (2014) 8674.

[37] Abdel Hafez A.I.I., Saber S.M., Mycoflora and Mycotoxin of Hazelnut (Corylus Avellana L.) and Walnut (Juglans Regia L.) Seeds in Egypt, 148 (1993) 137-147.

[38] Demir C., Şimşek O., Hamzacebi H ., Findikta Küf Floras1 ve Aflatoksin Oluşumlarının Araştırılması. Gıda 22 (2002) 291-295.

[39] Şimşek O., Arici M., Demir C., Mycoflora of Hazelnut ( Corylus avellana L.) and Aflatoxin Content in Hazelnut Kernels Artifically Infected with Aspergillus parasiticus, Food Science and Technology, 46 (2002) 194-196.

[40] Ayçiçek H., Aksoy A., Sayg1 S., Determination of Aflatoxin Levels in Some Dairy and Food Products Which Consumed in Ankara, Turkey, Food Control, 16 (2005) 263-266.

[41] Sanchis V., Quilez M. L., Viladrich R., Vinas I., Canela R., Hazelnuts as Possible Substrate for Aflatoxin Production, Journal Food Protection, 51 (1988) 289-292.

[42] Reddy M.J., Shetty H.S., Role of Seed Lipids in Aspergillus parasiticus Growth and Aflatoxin Production, Journal of the Science of Food and Agriculture, 59 (1992) 177 181.

[43] Baltaci C., İlyasoğlu H., Cavrar S., Aflatoxin levels in raw and processed hazelnuts in Turkey. Food Additives and Contaminants: Part B 5 (2012) 83-86

[44] Çöpür Y., Tozluoglu A., Özkan M., Evaluating pretreatment techniques for converting hazelnut husks to bioethanol. Bioresource Technology, 129 (2013) 182 90.

[45] Velioğlu S.D., Güner K.G., Velioğlu H.M., Çelikyurt G., Fındık Zarının Fırıncılık Ürünlerinde Kullanımı. Journal of Tekirdag Agricultural Faculty, 14 (2017) 34-38.

[46] Özer H., Findıklara Uygulanan Fiziksel ve Is1l Süreçlerde Aflatoksinler Üzerinde Etkisi, Doktora Tezi, Yıldız Teknik Üniversitesi Fen Bilimleri Enstitüsü, İstanbul (2009) 119.

[47] Vural A., Çakmak Ö., Erkan M. E., Aydın A. İstanbul Bölgesinde Tüketime Sunulan Fındık Ezmelerinde Aflatoksin Düzeylerinin Belirlenmesi, II. Ulusal Mikotoksin Sempozyumu Bildiriler Kitab1 (2005) 178.

[48] Günşen U. and Büyükyörük I., Aflatoxins in Retail Food Products in Bursa, Turkey, Veterinary and Human Toxicology, 44 (2002) 289-290.

[49] [49] Yu J., Chang, P.K., Bhatnagar, D., Cleveland, T.E., Cloning of a sugar utilization gene cluster in Aspergillus parasiticus. Biochim. Biophys. Acta 1493 (2000) 211-214. 